\title{
Type specimens of centipedes (Myriapoda, Chilopoda) in the National Museum, Prague (Czech Republic)
}

\author{
Petr Dolejšr \\ I Department of Zoology, National Museum-Natural History Museum, Cirkusová 1740, CZ-193 00, Praha \\ 9-Horni Počernice, Czech Republic \\ Corresponding author: Petr Dolejš (petr_dolejs@nm.cz)
}

Academic editor: Ivan H. Tuf | Received 22 September 2014 | Accepted 8 May 2015 | Published 30 June 2015

http://zoobank.org/93FC6F2B-4980-4355-AF48-E9EB0A204E92

Citation: Dolejš P (2015) Type specimens of centipedes (Myriapoda, Chilopoda) in the National Museum, Prague (Czech Republic). In: Tuf IH, Tajovský K (Eds) Proceedings of the $16^{\text {th }}$ International Congress of Myriapodology, Olomouc, Czech Republic. ZooKeys 510: 5-14. doi: 10.3897/zookeys.510.8636

\begin{abstract}
The centipede collection in the National Museum in Prague contains type material of 16 taxa (14 species and two subspecies), of which 15 were described by Luděk J. Dobroruka and one by Karl W. Verhoeff: Allothereua wilsonae Dobroruka, 1979; Chinobius alenae Dobroruka, 1980; Lithobius corrigendus Dobroruka, 1988; L. creticus Dobroruka, 1977; L. erythrocephalus mohelensis Dobroruka, 1959; L. evae Dobroruka, 1958; L. magurensis Dobroruka, 1971; L. purkynei Dobroruka, 1957; L. tatricus Dobroruka, 1958; L. tatricus monounguis Dobroruka, 1958; Monotarsobius homolaci Dobroruka, 1971; M. krali Dobroruka, 1979; Pachymerium dilottiae Dobroruka, 1976; P. hanzaki Dobroruka, 1976; Scolopendra aztecorum Verhoeff, 1934 and Strigamia olympica Dobroruka, 1977. Of these 16 taxa, five were described from the Czech Republic, three from Slovakia and eight from other countries (Greece, Iraq, Kyrgyzstan, Mexico, Nepal, Russia and Uzbekistan). The eight taxa described from the Czech and Slovak Republics are now considered as junior synonyms but the eight taxa described from the other countries are still valid.
\end{abstract}

\section{Keywords}

Zoological collection, Luděk Jindřich Dobroruka, Allothereua, Lithobius, Pachymerium, Scolopendra, Strigamia

Copyright Petr Dolejs. This is an open access article distributed under the terms of the Creative Commons Attribution License (CC BY 4.0), which permits unrestricted use, distribution, and reproduction in any medium, provided the original author and source are credited. 


\section{Introduction}

The most important part of the zoological collection of National Museum in Prague (NMP) is the type material. Up to now, catalogues of the type material of spiders (Růžička et al. 2005), vertebrates (Mlíkovský et al. 2011) and horsehair worms (Dolejš 2012) were published. The process of cataloguing the zoological type material is ongoing with this catalogue of centipede type material. There are no types of other myriapod classes despite 19 millipede and two symphylan taxa were described from the territory of the Czech Republic (Bezděk 2011). The centipede type material was deposited to the NMP in three distinct periods: 1930-1936 (material collected during expeditions organized by the NMP and people who were collaborating with the NMP), 1975-1978 (material collected by various collectors and provided to L. J. Dobroruka) and 2012-2014 (material found in Dobroruka's personal collection). Majority of the material was collected by Czechs and the new taxa originated from these collections were described by L. J. Dobroruka and K. W. Verhoeff. The latter author described new Scolopendra species based on material collected by Czech acarologist Prof. Jaroslav Štorkán (20 April 1890 - 1 June 1942) who was collecting for the NMP in 1920s and 1930s. Thus, it is not surprising that a part of material collected by him came back to the NMP.

The collection of centipedes (containing ca. 1500 specimens representing ca. 150 species and subspecies from about 40 countries) is perfectly organized and catalogued thanks to RNDr. Ing. Luděk Jindřich Dobroruka (20 October 1933 - 4 July 2004) who worked in the NMP as a curator of Invertebrates in 1956 and continued with his work on centipedes in the NMP also in 1970s. His work resulted in publishing of catalogues of non-type Bulgarian (Dobroruka 1977a), Greek (Dobroruka 1977b) and Brazilian (Dobroruka 1979a) centipedes deposited there. Despite collaborating with the NMP, some types described by him remained in his personal collection and a part of them were deposited to the NMP after the work of Tuf et al. (2008). Unfortunately, the destination of several Dobroruka's types is still unknown. More information about L. J. Dobroruka can be found in Felix (2004a, b), Hanák (2004), Kellnerová (2004), Růžička (2005), Tuf (2005) and Bartoš (2006).

\section{Methods}

All the specimens are preserved in $80 \%$ ethanol. Nomenclatural issues follow the International Code of Zoological Nomenclature (ICZN 1999, 2012). Orig. = original combination (as proposed in the original publication), the first page with descriptions including figures and sex of the illustrated animal. Now = current status of the taxon. For grid squares of Czech and Slovak localities, see Buchar (1982) and Pruner and Míka (1996). Condition of the type material is provided as follows: excellent - good - reasonable - poor. 


\section{Results}

\section{Order: Scutigeromorpha}

Family: Scutigeridae

\section{Allotherena wilsonae Dobroruka, 1979}

Orig. Allothereua wilsonae Dobroruka, 1979b: 101, figs 1-5 (ㅇ).

Now. Allothereua wilsonae Dobroruka, 1979. The status of this species has never been revised since its original description.

Holotype. NMP P6E-1761, $q$ in poor condition (in two pieces, legs detached), collected by Jane M. Wilson on 14 October 1971 in one of the tents of the camp, near Mahendra Cave, Pokhara Valley, Nepal; $28^{\circ} 14.00^{\prime} \mathrm{N}, 83^{\circ} 59.00^{\prime} \mathrm{E}$.

\section{Order: Scolopendromorpha}

Family: Scolopendridae

\section{Scolopendra aztecorum Verhoeff, 1934}

Orig. Scolopendra aztecorum Verhoeff, 1934: 49.

Now. Scolopendra aztecorum Verhoeff, 1934. Valid species according to CupulMagaña (2013).

Syntype. NMP P6E-1303, one adult specimen in good condition, collected by Jaroslav Štorkán in 1930 under decaying cactuses, La Paz, Baja California Sur Region, Mexico; $24^{\circ} 8.28^{\prime} \mathrm{N}, 110^{\circ} 18.58^{\prime} \mathrm{W}$.

Note. Other syntypes are deposited in the Zoologisches Museum der HumboldtUniversität, Berlin, Germany under number ZMB 13378 (Moritz and Fischer 1979); in the Bavarian State collection, Munich, Germany under numbers ZSM/Myr20051044 and ZSM/Myr-20051045 (SysTax 2015); and in the Naturalis Biodiversity Center, Leiden, the Netherlands under number RMNH.CHIL.154 (C. A. MartínezMuñoz in litt.). Both Shelley (2006) and Cupul-Magaña (2013) erroneously regarded the specimen from Berlin as a holotype despite Verhoeff (1934) did not designate any type specimen and despite Moritz and Fischer (1979) referred to it as "Syntypus".

\section{Order: Geophilomorpha Family: Geophilidae}

\section{Pachymerium dilottiae Dobroruka, 1976}

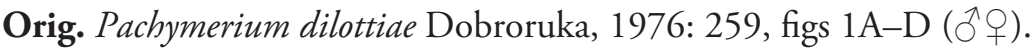


Now. Pachymerium dilottiae Dobroruka, 1976. The status of this species has never been revised since its original description.

Holotype. NMP P6E-1326, + in reasonable condition (in two pieces, head mounted separately on a permanent slide), collected by Vlasta Kálalová-di Lotti in 1929 in Baghdad, Iraq; $33^{\circ} 20.43^{\prime} \mathrm{N}, 44^{\circ} 24.05^{\prime} \mathrm{E}$.

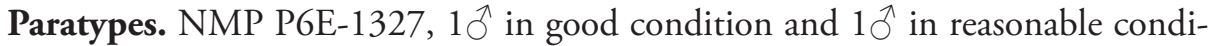
tion (missing the caudal part of the body), same data as holotype.

\section{Pachymerium hanzaki Dobroruka, 1976}

Orig. Pachymerium hanzaki Dobroruka, 1976: 260, figs 2A-E (§)).

Now. Pachymerium hanzaki Dobroruka, 1976. The status of this species has never been revised since its original description.

Holotype. NMP P6E-1328, ô in reasonable condition (head mounted separately on a permanent slide), collected by Vlasta Kálalová-di Lotti in 1929 in Baghdad, Iraq; $33^{\circ} 20.43^{\prime} \mathrm{N}, 4^{\circ} 24.05^{\prime} \mathrm{E}$.

\section{Family: Linotaeniidae}

\section{Strigamia olympica Dobroruka, 1977}

Orig. Strigamia (Strigamia) olympica Dobroruka, 1977b: 163, figs 5-8 (中).

Now. Strigamia olympica Dobroruka, 1977. Valid species according to Bonato et al. (2012).

Holotype. NMP P6E-1352, 9 in reasonable condition, collected by Karel Táborský on 5 June 1935 in Óros Ólympos Mt., Greece; 40³.72'N, 22²0.70'E.

\section{Order: Lithobiomorpha Family: Lithobiidae}

\section{Lithobius (Chinobius) alenae (Dobroruka, 1980)}

Orig. Chinobius alenae Dobroruka, 1980: 92, figs 1-6 (+).

Now. Lithobius (Chinobius) alenae (Dobroruka, 1980). The status of this species has never been revised since its original description.

Holotype. NMP P6E-3912, + in reasonable condition, collected by Alena Čepická on 5 July 1977 under bark of fallen trees in Voronezhskove, $30 \mathrm{~km}$ NE from

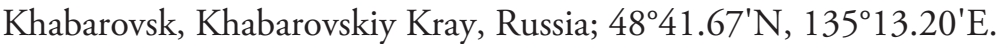

Paratype. NMP P6E-3913, + in good condition, same data as holotype. 


\section{Lithobius (Lithobius) corrigendus Dobroruka, 1988}

Orig. Lithobius corrgendus (sic!) Dobroruka, 1988: 6 (nomen novum for Lithobius parvus Folkmanová, 1946).

Now. Junior synonym of Lithobius (Lithobius) lucifugus L. Koch, 1862 (Tuf et al. 2008).

Neotype. NMP P6E-3901, đ̂̉ in reasonable condition, collected by Luděk J. Dobroruka on 12 August 1997 on the left bank of the Dyje river by Devět mlýnů, Podyjí National Park, Znojmo District, Jihomoravský Region, Czech Republic; 4849.08'N, $15^{\circ} 58.38^{\prime} \mathrm{E}$ (7161d); designated by Tuf et al. (2008).

Note. Another (non-type) female specimen in excellent condition (NMP P6E3902) determined by Dobroruka as L. corrigendus was revised as Lithobius (Lithobius) latro Meinert, 1872 by Jolanta Wytwer, Ivan H. Tuf and Karel Tajovský in 2006.

\section{Lithobius (Lithobius) creticus Dobroruka, 1977}

Orig. Lithobius creticus Dobroruka, 1977b: 161, figs 1-4 (P).

Now. Lithobius (Lithobius) creticus Dobroruka, 1977. Valid species according to Zapparoli (2002).

Holotype. NMP P6E-1350, $q$ in good condition, collected by Josef Mařan and Otakar Štěpánek in 1937 in Óros Ídi Mt., Crete, Greece; 35 14.04'N, 24²46.84'E.

Paratype. NMP P6E-1351, ô in good condition, same data as holotype.

\section{Lithobius (Lithobius) erythrocephalus mobelensis Dobroruka, 1959}

Orig. Lithobius erythrocephalus mohelensis Dobroruka, 1959: 105, figs 3 (đ), 4 ().

Now. Lithobius (Lithobius) erythrocephalus C. L. Koch, 1847 (Tuf et al. 2008).

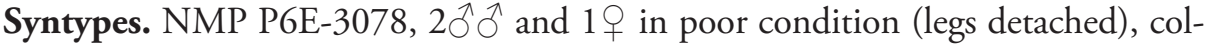
lected by Luděk J. Dobroruka in April and June 1955 in Serpentine Steppe of Mohelno, Třebíč District, Vysočina Region, Czech Republic; 496.47'N, 16²11.25'E (6863c).

\section{Lithobius (Lithobius) evae Dobroruka, 1958}

Orig. Lithobius (Lithobius) evae Dobroruka, 1958b: 26, figs 1 (ङ), 2 (ㅇ).

Now. Junior synonym of Lithobius (Lithobius) tenebrosus Meinert, 1872 (Tuf et al. 2008).

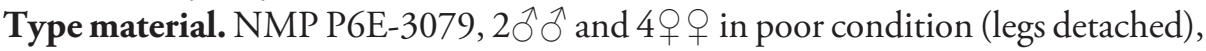
collected by Eva M. Homoláčová and Miloš E. Homoláč on 14 September 1956 among fallen beech leaves in Bukovec Hill near Jizerka, Jizerské hory Mts., Jablonec nad Nisou District, Liberec Region, Czech Republic; 50²8.86'N, 15²1.47'E (5158c).

Note. Male holotype and three female paratypes were not labelled and thus indistinguishable among the type material mentioned. 


\section{Lithobius (Monotarsobius) homolaci Dobroruka, 1971}

Orig. Monotarsobius homolaci Dobroruka, 1971: 262, fig. 2 (đ).

Now. junior synonym of Lithobius (Sigibius) burzenlandicus Verhoeff, 1931 (Tuf et al. 2008).

Holotype. NMP P6E-1454, $\widehat{O}$ in good condition, collected (sifted from beech leaf litter) by Miloš E. Homoláč in September 1959 in Spišská Magura Mts., Kežmarok District, Prešov Region, Slovakia; 49 $17.04^{\prime} \mathrm{N}, 20^{\circ} 22.38^{\prime} \mathrm{E}$ (6788a).

Paratype. NMP P6E-1455, 9 in reasonable condition, same data as holotype.

\section{Lithobius (Monotarsobius) krali (Dobroruka, 1979)}

Orig. Monotarsobius krali Dobroruka, 1979c: 161, figs 1-3 (ð゚)

Now. Lithobius (Monotarsobius) krali (Dobroruka, 1979). Valid species according to Dányi and Tuf (2012).

Holotype. NMP P6E-1762, $\widehat{\sigma}$ in good condition, collected by Josef Král on 8 July 1976 in Ala Archa, Chüy Region, Kyrgyzstan; 42³8.70'N, 74²8.73'E.

Paratype. NMP P6E-1763, + in reasonable condition, collected by Josef Král on 3 July 1976 in Gora Chimgan Mt., Toshkent Region, Uzbekistan; 41 $40.45^{\prime} \mathrm{N}$, $69^{\circ} 42.90^{\prime} \mathrm{E}$.

\section{Lithobius (Lithobius) magurensis Dobroruka, 1971}

Orig. Lithobius magurensis Dobroruka, 1971: 261, fig. $1\left({ }^{\Uparrow}\right)$.

Now. Junior synonym of Lithobius (Lithobius) muticus C. L. Koch, 1847 (Tuf et al. 2008).

Holotype. NMP P6E-1452, đ̂ in excellent condition, collected by Miloš E. Homoláč in September 1959 in Spišská Magura Mts., Kežmarok District, Prešov Region, Slovakia; $49^{\circ} 17.04^{\prime} \mathrm{N}, 20^{\circ} 22.38^{\prime} \mathrm{E}$ (6788a).

Paratype. NMP P6E-1453, 9 in good condition, same data as holotype.

\section{Lithobius (Lithobius) purkynei Dobroruka, 1957}

Orig. Lithobius (Lithobius) purkyněi Dobroruka, 1957: 174, figs 1A-B (q).

Now. Junior synonym of Lithobius (Lithobius) macilentus L. Koch, 1862 (Tuf et al. 2008).

Type material. NMP P6E-3080, $5 q 9$ in poor condition (legs detached), collected by Luděk J. Dobroruka on 17 and 22 June 1956 in Boreč, Litoměřice District, Ústí nad Labem Region, Czech Republic; 50³0.85'N, 1359.31'E (5449d). 
Note. Female holotype and four female paratypes were not labelled and thus indistinguishable among the type material mentioned. Other (non-type) male and female specimens (NMP P6E-1290) determined by Dobroruka as L. purkynei were mentioned in Dobroruka (1977c).

\section{Lithobius (Lithobius) tatricus Dobroruka, 1958}

Orig. Lithobius (Archilithobius) tatricus Dobroruka, 1958a: 115, figs 1-2 (§̊) ), 3 (†).

Now. Junior synonym of Lithobius (Lithobius) mutabilis L. Koch, 1862 (Tuf et al. 2008).

Type material. NMP P6E-3081, three specimens in a poor condition (legs detached), collected by Luděk J. Dobroruka on 26 June 1955 from sieved material and under bark of fallen trees in Bielovodská dolina Valley, Belanske Tatry Mts., Poprad District, Prešov Region, Slovakia; 49¹3.31'N, 20⒍14'E (6786d).

Note. Male holotype, three male and one female paratypes were not labelled and thus indistinguishable among the type material mentioned. Other (non-type) male and female specimens (NMP P6E-1376, P6E-1380, P6E-1427, P6E-1439 and P6E-3082) determined by Dobroruka as L. tatricus were mentioned in Dobroruka (1977c, 1998).

\section{Lithobius (Lithobius) tatricus monounguis Dobroruka, 1958}

Orig. Lithobius (Archilithobius) tatricus monounguis Dobroruka, 1958b: 27.

Now. Junior synonym of Lithobius (Lithobius) latro Meinert, 1872 (Tuf et al. 2008).

Holotype. NMP P6E-3082, $\widehat{o}$ in poor condition (legs detached), collected by Eva M. Homoláčová and Miloš E. Homoláč on 14 September 1956 under moist beech leaves in Bukovec Hill near Jizerka, Jizerské hory Mts., Jablonec nad Nisou District, Liberec Region, Czech Republic; 5048.86'N, 15²1.47'E (5158c).

\section{Conclusions}

The zoological collection of the National Museum in Prague hosts (among others) type material of 16 centipede taxa. Both sctutigeromophs (Scutigeridae) and scolopendromorphs (Scolopendridae) are represented by one species, geophilomorphs (Geophilidae and Linotaenidae) by three species and lithobiomorphs (Lithobiidae) by 11 species and subspecies. Five species from the first three orders (Allothereua wilsonae, Scolopendra aztecorum, Pachymerium dilottiae, P. hanzaki and Strigamia olympica) and three species from Lithobiomorpha (Lithobius alenae, L. creticus and L. krali) are currently valid. The eight remaining lithobiomorph species and subspecies (Lithobius corrigendus, L. erythrocephalus mohelensis, L. evae, L. homolaci, L. magurensis, L. purkynei, L. tatricus and L. tatricus monounguis) are now considered as junior synonyms. 


\section{Acknowledgments}

I thank Ivan H. Tuf and Jana Dobroruková for information about L. J. Dobroruka and for providing me appropriate literature. I am grateful to Carlos A. Martínez-Muńoz for information about Scolopendra aztecorum. Finally, I would like to thank two anonymous reviewers for their helpful comments and suggestions improving the earlier version of the manuscript. This study was fully supported by the project NAKI (DF12P01OVV021).

\section{References}

Bartoš L (Ed.) (2006) RNDr. Ing. Luděk J. Dobroruka *20. 10. 1933, † 4. 7. 2004. Zprávy ČSEtS 20: 1-30. http://www.csets.sk/soubory/zpravy202.pdf [In Czech]

Bezděk J (2011) Přehled živočišných druhů popsaných z území České republiky [A review of animal species described from the Czech Republic]. Mendelova univerzita v Brně, Brno, 420 pp. [In Czech, English summary]

Bonato L, Dányi L, Socci AA, Minelli A (2012) Species diversity of Strigamia Gray, 1843 (Chilopoda: Linotaeniidae): a preliminary synthesis. Zootaxa 3593: 1-39. http://www. mapress.com/zootaxa/2012/f/z03593p039f.pdf

Buchar J (1982) Způsob publikace lokalit živočichů z území Československa. Publication of faunistic data from Czechoslovakia. Věstník Československé společnosti zoologické 46: 317-317. [In Czech, Russian and English summary]

Cupul-Magaña FG (2013) La diversidad de los ciempiés (Chilopoda) de México. Dugesiana 20(1): 17-41. http://dugesiana.cucba.udg.mx/dugesiana_agost2013/17-42.pdf

Dányi L, Tuf IH (2012) Lithobius (Monotarsobius) franciscorum sp. nov., a new lithobiid species from the Altai, with a key to the Central Asian species of the subgenus (Chilopoda: Lithobiomorpha). Zootaxa 3182: 16-28. http://www.mapress.com/zootaxa/2012/f/ z03182p028f.pdf

Dobroruka L (1957) Neue Chilopoda aus dem Böhmischen Mittelgebirge. Zoologischer Anzeiger 159(7-8): 174-179.

Dobroruka LJ (1958a) Př́spěvek k poznání stonožek z Tater (Chilopoda). Beitrag zur Kenntnis der Tausendfüssler aus Tatra (Chilopoda). Věstník Československé zoologické společnosti 22(2): 113-120. [In Czech, German summary]

Dobroruka LJ (1958b) Neue Chilopoden aus Böhmen. Zoologischer Anzeiger 160(1-2): 25-28.

Dobroruka LJ (1959) Chilopoda státní přírodní rezervace Mohelno. Chilopoden des staatlichen Naturschutzgebietes Mohelno. Ochrana př́rody 14(4): 104-106. [In Czech, German summary]

Dobroruka LJ (1971) Chilopoda von Belanské Tatry und Spišská Magura. Věstník Československé společnosti zoologické 35(4): 261-264.

Dobroruka LJ (1976) Einige Chilopoden aus Irak. Věstník Československé společnosti zoologické 40(4): 259-262. 
Dobroruka LJ (1977a) Bulgarische Chilopoden in der Sammlung von Nationalmuseum Praha. Věstník Československé společnosti zoologické 41(1): 5-7.

Dobroruka LJ (1977b) Chilopoden aus Griechenland und Kreta in der Sammlung des Nationalmuseums Prag. Věstník Československé společnosti zoologické 41(3): 161-164.

Dobroruka LJ (1977c) Neue Funde seltener Chilopoden-Arten in der Tschechoslowakei (Myriopoda: Chilopoda). Věstník Československé společnosti zoologické 41(4): 245-247. Dobroruka LJ (1979a) Notes on the chilopods of Brazil in the collection of the National Museum Prague. Věstník Československé společnosti zoologické 43(2): 98-100.

Dobroruka LJ (1979b) Allothereua wilsonae sp. n., a new centipede from Nepal (Chilopoda: Scutigeromorpha: Thereuoneminae). Věstník Československé společnosti zoologické 43(2): 101-103.

Dobroruka LJ (1979c) Zur weiteren Kenntnis der zentralasiatischen Chilopoden. Věstník Československé společnosti zoologické 43(3): 161-164.

Dobroruka LJ (1980) Chinobius alenae sp. n., eine neue Chilopoden-Art aus dem Fernen Osten (Chilopoda: Lithobiomorpha). Věstník Československé společnosti zoologické 44(2): 92-93.

Dobroruka LJ (1988) Chilopoda of the Białowieża Forest. National parks and nature reserves 9(1): 5-7.

Dobroruka LJ (1998) Annotated preliminary checklist of Chilopoda of the Podyjí National Park. Thayensia (Znojmo) 1: 131-136.

Dolejš P (2012) Type specimens of gordioids (Nematoida: Nematomorpha) in the National Museum, Prague. Journal of the National Museum (Prague), Natural History Series 181(4): 21-25. http://www.nm.cz/publikace/publikace-download.php?name=File1\&dir $=\operatorname{archiv} \&$ table $=$ tabPublikaceArchiv $\&$ id $=3597$

Felix J (2004a) Za významným zoologem Lud'kem J. Dobrorukou [After an outstanding zoologist Luděk J. Dobroruka]. Živa 52(4): XLII. http://ziva.avcr.cz/files/ziva/pdf/za-vyznamnym-zoologem-ludkem-j-dobrorukou.pdf [In Czech]

Felix J (2004b) Za RNDr. Ing. Ludkem J. Dobrorukou [After RNDr. Ing. Luděk J. Dobroruka]. TamTamy 7(4): 23-24. [In Czech]

Folkmanová B (1946) Dva nové druhy Lithobiidů z Křivoklátska. Deux nouveaux éspéces de Lithobius. Věstník Československé zoologické společnosti 10: 90-100. [In Czech, French summary] Hanák V (2004) Za RNDr. Ing. Lud'kem J. Dobrorukou. In memoriam RNDr. Ing. Luděk J. Dobroruka. Lynx, n. s. 35: 273-280. http://www.nm.cz/publikace/publikace-download. php? name=File1 $\&$ dir $=$ archiv\&table=tabPublikaceArchiv\&id=2218 [In Czech]

ICZN (1999) International code of zoological nomenclature. Fourth Edition. The International Trust for Zoological Nomenclature, London.

ICZN (2012) International Commission on Zoological Nomenclature. Amendment of Articles 8, 9, 10, 21 and 78 of the International Code of Zoological Nomenclature to expand and refine methods of publication. ZooKeys 219: 1-10. doi: 10.3897/zookeys.219.3944

Kellnerová D (2004) Malá tajemství Lud'ka J. Dobroruky [Little secrets of Luděk J. Dobroruka]. Bedrník 2(6): 18-20. [In Czech]

Koch CL (1847) System der Myriapoden. In: Herrich-Schäffer L (Ed.) Kritische Revision der Insectenfauna Deutschlands. Pustet, Regensburg, 3: 1-270. 
Koch L (1862) Die Myriapodengattung Lithobius. JL Lotzbeck, Nürnberg, 94 pp.

Meinert F (1872) Myriapoda Musaei Hauniensis. Bidrag til Myriapoderns Morphologi og Systematik. II. Lithobiini. Naturhistorisk Tidsskrift (3) 8: 281-344. [In Danish]

Mlíkovský J, Benda P, Moravec J, Šanda R (2011) Type specimens of recent vertebrates in the collections of the National Museum, Prague, Czech Republic. Journal of the National Museum (Prague), Natural History Series 180(10): 133-164. http://www.nm.cz/publikace/ publikace-download.php?name=File1 $\&$ dir $=$ archiv $\&$ table $=$ tabPublikaceArchiv $\& i d=2997$

Moritz M, Fischer S-C (1979) Die Typen der Myriapoden-Sammlung des Zoologischen Museums Berlin. II. Chilopoda. Mitteilungen aus dem Zoologischen Museum in Berlin 55(2): 297-352. doi: 10.1002/mmnz.4830550215

Pruner L, Míka P (1996) Seznam obcí a jejich částí v České republice s čísly mapových polí pro sítové mapování. List of settlements in the Czech Republic with associated map field codes for faunistic grid mapping system. Klapalekiana 32(Suppl.): 1-175. [In Czech, English abstract and summary]

Růžička V (2005) In memoriam RNDr. Ing. Luděk J. Dobroruka, 1933-2004. Arachnologische Mitteilungen 29: 64. doi: 10.5431/aramit2914

Růžička V, Kůrka A, Buchar, Řezáč M (2005) Czech Republic-the type material of spiders (Araneae). Časopis Národního muzea, Řada př́rodovědná 174(1-4): 13-64. http://www. nm.cz/publikace/publikace-download.php?name=File $1 \&$ dir $=$ archiv $\&$ table=tabPublikace Archiv\&id=164

Shelley RM (2006) A chronological catalog of the New World species of Scolopendra L., 1758 (Chilopoda: Scolopendromorpha: Scolopendridae). Zootaxa 1253: 1-50. http://www.mapress.com/zootaxa/2006f/z01253p050f.pdf

SysTax (2015) A Database System for Systematics and Taxonomy: Scolopendra aztecorum Verhoeff, 1934. http://www.biologie.uni-ulm.de/cgi-bin/query_all/details.pl?id=85045\&stuf e=7\&typ=ZOO\&sid=T\&lang=e\&pr=nix

Tuf IH (2005) Luděk Jindřich Dobroruka [1993-2004]. Bulletin du Centre International de Myriapodologie 38: 7-10. http:/www.ekologie.upol.cz/ad/tuf/pdf/papers/Tuf_2005b.pdf

Tuf IH, Wytwer J, Tajovský K (2008) On the identity of the species described in the genus Lithobius Leach, 1814 by L. J. Dobroruka from the former Czechoslovakia (Czech and Slovak Republics) (Chilopoda: Lithobiomorpha). Zootaxa 1788: 37-46. http://www.mapress.com/zootaxa/2008/f/z01788p046f.pdf

Verhoeff KW (1931) Chilopoden der Insel Elba (Isopoden). Zoologischer Anzeiger 95(11-12): 302-312.

Verhoeff KW (1934) Beiträge zur Systematik und Geographie der Chilopoden. Zoologische Jahrbücher, Abteilung für Systematik 66: 1-112.

Zapparoli M (2002) A catalogue of the centipedes from Greece (Chilopoda). Fragmenta Entomologica 34: 1-146. 